\title{
Tracing the footsteps of IVS-I-130 G-C mutation of the human hemoglobin beta globin gene: From Şanlıurfa to Askeriye, Burdur, Turkey İnsan hemoglobin beta globin genindeki IVS-I-130 G-C mutasyonu izlerinin takibi: Şanlıurfa'dan Askeriye'ye, Burdur, Türkiye
}

\section{Çiğdem Altay}

Honorary Member of the Turkish Academy of Sciences, Ankara, Turkey

The first report of IVS-I-130 G-C mutation was of a Turkish patient from Askeriye, a small village near Burdur in southern Turkey, which was published in 1990 [1]. Later, a Japanese patient with the mutation in a heterozygous state was reported in 1992 [2]. The mutation has subsequently been reported numerous times in patients of Askeriye ancestry from İzmir and Antalya, Turkey [1,3]. In this issue of the journal, Çiçek et al. reports on the frequency of thalassemia mutations in Şanllurfa in southeastern Turkey [4]; they observed the IVSI-130 G-C mutation in 6 alleles (2.5\%) in families without any known association to Askeriye.

It is interesting to note that Kemal Tahir mentions a fort and a field hospital in nearby Burdur during World War I in the semi-biographical novel about his father entitled, Bir Mülkiyet Kalesi, which translates as, A Fortress of Property. The place he mentions is most probably Askeriye, as Askeriye means military settlement [5]. According to the novel, during World War I, probably in 1917, a small group of people from southeastern Turkey composed of very old men and women, and young women and chil- dren, but no young or middle aged men, settled in the houses recently deserted by the Armenians in the area (Askeriye). They all spoke Kurdish, and lived under conditions of poor sanitation, hunger, and malnourishment [5]. The young women of the group immediately began to exchange sex with the soldiers for bread. This continued for about 1 year, and then the group returned to their home in southeastern Turkey [5] in 1918, most probably leaving behind a few donors of the IVS-I-130 G-mutation, such as young women and/or their newborns.

This is only one of many stories about gene donation via population movement; however, it is well known that Anatolian history includes many east-to-west and west-to-east migrations. As such, it is difficult to conclude that the above story about thalassemia gene donation is true, however likely it may be. I advise the authors to first demonstrate via haplotype analysis that the mutations observed in Askeriye and Şanlıurfa both occurred on chromosome 11. Additionally, the story told in the novel needs to be verified by military and local city archives. 


\section{References}

1. Öner R, Altay Ç, Gurgey A, Aksoy M, Kilinç Y, Stoming TA, Reese AL, Kutlar A, Kutlar F, and Huisman THJ. Beta thalassemia in Turkey. Hemoglobin 1990;14:1-13. [CrossRef]

2. Yamamoto K, Yamamoto K, Hattori Y, Yamashiro Y, Hoshitani M, Morishita M, Ohba Y, Katahira H, Karasawa M, Omine M. Two beta-thalassemia mutations in Japan: codon 121 (GAA----TAA) and IVS-I-130 (G----C). Hemoglobin 1992;16:295-302. [CrossRef]
3. Nal N, Manguoglu AE, Sargin CF, Keser I, Kupesiz A, Yesilipek A, Luleci G. Two rare mutations in Turkey: IVS I.130(G-C) and IVS II.848(C-A). Clin Lab Haematol. 2005; 27:274-7. [CrossRef]

4. Ayçiçek A, Koc A, Özdemir ZC, Bilinç H, Koçyiğit A, Dilmec F. $\beta$-thalassemia mutations in Sanliurfa province Turkey. 264-8.

5. Kemal Tahir. Bir Mülkiyet Kalesi. Istanbul: Tekin Yayınevi, 2nd ed. 1982:165-78. 